\title{
Anxiety Level of Pregnant Women before Pregnancy Termination for Fetal Abnormality
}

\author{
Merve Geylani, ${ }^{1}$ (i) Sibel Doğan,2 (1) Ali Timuçin Atayoğlu³
}

'Department of Nursing, Faculty of Health Sciences, Istanbul Kent University, Istanbul, Turkey

${ }^{2}$ Department of Psychiatric Nursing, Faculty of Health Sciences, Istanbul Medipol University, Istanbul, Turkey

${ }^{3}$ Department of Family Medicine, Istanbul Medipol University, International Faculty of Medicine, Istanbul, Turkey

\section{ABSTRACT}

Objectives: Holistic approaches in health care services consider all aspects of individuality. This research was conducted as a descriptive study to evaluate the anxiety level of pregnant women before the termination of the pregnancy for fetal abnormalities.

Methods: This descriptive and cross-sectional study comprised pregnant women who were admitted to the prenatal diagnosis and treatment unit before pregnancy termination for a severe fetal abnormality. As the data collection tool, a questionnaire containing the descriptive and obstetric characteristics of the pregnant women, their feelings and thoughts about pregnancy and the State-Trait Anxiety Inventory were used in this research. In the evaluation of the research data, percentage values, arithmetic mean, standard deviation, median, minimum and maximum values were given as descriptive statistics of the data.

Results: This study consisted of 83 pregnant women. The findings showed that 49 (59.0\%) of pregnant women experienced sadness, and 41 (49.4\%) needed psychological support before the termination of pregnancy. The mean State-Trait Anxiety Inventory score of the pregnant women was $60.7 \pm 11.6$, and that they experienced high levels of anxiety.

Please cite this article as: Geylani M, Doğan S, Atayoğlu AT. Anxiety Level of Pregnant Women before Pregnancy Termination for Fetal Abnormality. Anatol J Family Med 2020;3(1):52-58.

Address for correspondence: Dr. Ali Timuçin Atayoğlu. Department of Family Medicine, Istanbul Medipol University, International Faculty of Medicine, Istanbul, Turkey

Phone: +905324649576

E-mail: atatayoglu@gmail.com

Received Date: 18.08.2019

Accepted Date: 24.10 .2019

Published online: 01.04 .2020

(C) Copyright 2020 by Anatolian Journal of Family Medicine Available online at www.anatoljfm.org

OPEN ACCESS

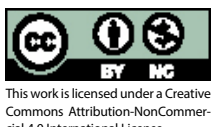

Conclusion: The findings suggest that pregnant women before the termination of pregnancy for severe fetal abnormalities should be evaluated and supported psychosocially.

Keywords: Anxiety, Congenital Abnormalities, fetus, holistic health, pregnancy

\section{INTRODUCTION}

Pregnancy is a very specific period in a woman's life that many changes are observed not only on the biological plane but also in her psychological functioning. ${ }^{[1]}$ Pregnancy can be a stressful experience for women due to these changes and from their concerns about childbirth and the health of their offspring. ${ }^{[2,3]}$ In some cases, this process may become more troublesome, and pregnancy cannot continue in a healthy way. Medically undesirable conditions may also develop during pregnancy. Anomalies constitute an important group of these conditions. ${ }^{[4]}$ Abnormality, in medicine, means developing differently than normal. The fetal abnormality is that the structure, shape and function of the fetus are not normal and is different from the expected standard type and normal. ${ }^{[5]}$ Today, many anomalies can be detected in early pregnancy by prenatal diagnostic tests. ${ }^{[6]}$ It is possible to detect problems developed or developing in the fetus with routine tests that are specific to that trimester and other tests that are performed where necessary. Severe fetal abnormalities may cause perinatal death and contribute significantly to permanent disability and hospitalization. ${ }^{[7]}$

Termination of pregnancy is an important event in women's lives. Pregnancy termination 
for fetal abnormality may have profound psychological consequences for women. ${ }^{[8]}$ The decision to terminate the pregnancy in the later weeks of pregnancy becomes much more difficult, and it has a big impact on pregnant women who make this decision. ${ }^{[9-10]}$ In making the decision to terminate the pregnancy, the psychological, religious, cultural and material characteristics of the parents particularly affect this decision. However, in any case, it is very sad and difficult for the family to make this decision. After the decision to terminate the pregnancy, couples may experience guilt, loss and regret, causing anxiety and trauma.

The diagnosis of fetal abnormality disturbs every parent. Suddenly, the desired, long-awaited pregnancy loses its importance. Although couples cannot express their feelings at first, and appear calm, the first reaction is shock and denial. It is difficult for couples to accept this event. Some parents may take a stand against their partner and doctor. Some parents may be depressed during this process, some respond by mourning, but their duration and severity continue to fluctuate until the parents accept the situation. ${ }^{[1]}$ Couples who decide to terminate the pregnancy due to fetal abnormality are not only confronted with pregnancy loss but also with the decision to terminate consciously. ${ }^{[12]}$ Thus, it is very important to integrate psychological assessment and supportive psychological approaches towards the mother candidate into routine care services with the decision to terminate. ${ }^{[13]}$ Women consider such a decision very difficult, and any women who terminate the pregnancy because of a fetal anomaly suffer from significant longterm psychological morbidity. ${ }^{[14]}$

Holistic approaches in health care services consider all aspects of individuality, including physical, mental, social and spiritual. ${ }^{[15]}$ In this context, this study was planned to investigate the anxiety status of pregnant women who were proposed termination of pregnancy for fetal abnormality. Because the literature on this subject is very limited, it is thought that the results of our study will contribute to the practices to be planned for pregnant women and families in such a termination process.

\section{METHOD}

This descriptive and cross-sectional study comprised pregnant women who were admitted to the prenatal diagnosis and treatment unit of Istanbul University, Medical Faculty Hospital between August 2017 and February 2018 before pregnancy termination for a severe fetal abnormality. This research was conducted in the form of the application of data collection tools (Questionnaire, State-Trait Anxiety Inventory) after the pregnant women who gave termination decisions for their pregnancies and before the procedure was performed. They were admitted to the unit and inter- viewed face-to-face. They were informed about this study to be conducted, and the consent documents of the volunteers who agreed to participate were obtained. Each interview took about 15 minutes.

\section{Questionnaire Form}

In this form, the first five questions were about demographic characteristics and the remaining 10 questions were about obstetric characteristics of pregnant women. The questionnaire form includes questions, such as age, education, the status of consanguineous marriages and the status of the previous termination of pregnancy.

\section{State-Trait Anxiety Inventory}

The State-Trait Anxiety Inventory is one of the first tests to assess both state and trait anxiety separately. Spielberger et al. developed the State-Trait Anxiety Inventory ${ }^{[16]}$, and it was translated into Turkish by Necla Öner and Le Compte. [17] The inventory is a combination of two scales with 20 questions in total, and both scales have anxiety absent and anxiety present questions. Anxiety absent questions represent the absence of anxiety in a statement like, "I feel secure." Anxiety present questions represent the presence of anxiety in a statement like "I feel worried." Each measure is rated on a 4-point scale, which is as follows: 1.) not at all, 2.) somewhat, 3 .) moderately so, 4 .) very much so. The score ranges of the scale: 0-19 points (none), 20-39 points (mild anxiety), 40-59 points (moderate anxiety), 60-79 points (severe anxiety), 80 points and above (extreme level of anxiety/panic). Low scores indicate a mild form of anxiety, whereas median scores indicate a moderate form of anxiety, and high scores indicate a severe form of anxiety. If the total anxiety score is higher than 60 points, it means that the individual needs professional support.

\section{Data Analysis}

IBM SPSS Statistics 22 statistical software package was used to analyze the research data in this study. Percentage values, arithmetic mean, standard deviation, median, minimum and maximum values were given as descriptive statistics of the data. Shapiro-Wilk normality test was used to determine whether the data were distributed normally. As the data were not normally distributed, the Mann-Whitney $\mathrm{U}$ test was used in independent two-group comparisons, and the Kruskal-Wallis test was used in the comparison of more than two independent groups. The statistical significance level was accepted as $p<0.05$.

\section{Ethical Aspect of this Research}

This study was approved by the Ethics Committee of Medipol University (21/07/2016 No: 385) and written permission 
was obtained from the Istanbul University Medical Faculty. Hospital where this research was carried out. Before starting the data collection, "Volunteer Consent" principle and "Volunteerism principle" were fulfilled by informing the participants about this research and obtaining their signed "Informed Consent Forms", the principle of "Respect for Autonomy" was fulfilled by stating that they were free to participate in this research, and the principle of "Confidentiality and Protection of Privacy" was fulfilled by stating that the information of the patients participating in this research would be kept confidential.

\section{RESULTS}

The sample of this study consisted of 83 pregnant women without a past medical history of anxiety disorders or any mental problems. The State-Trait Anxiety Inventory mean scores of the pregnant women before the termination of pregnancy were $60.7 \pm 11$.6. Table 1 shows the comparison of the scores obtained from the State-Trait Anxiety Inventory before termination of pregnancy according to the descriptive characteristics of the pregnant women. When the mean State-Trait Anxiety Inventory scores of pregnant women before termination of pregnancy were examined according to the descriptive characteristics of pregnant women, the mean scores before termination of pregnancy were found to be higher in the pregnant women between 26-34 years of age, who and her husband had postgraduate degree, whose husband worked and had moderate/ very good economic status, and who did not have consanguineous marriages. However, the difference between the groups was not statistically significant $(p>0.05)$. A statistically significant difference was found between the status of consanguineous marriages of the pregnant women and the mean State-Trait Anxiety Inventory score, and the anxiety levels of the non-consanguineous marriages were higher $(p=0.021)$.

Table 2 shows the comparison of the scores obtained from the State-Trait Anxiety Inventory before termination of pregnancy according to obstetric characteristics of pregnant women. As can be seen in Table 2, it was found that the mean scores obtained from the State-Trait Anxiety Inventory of pregnant women were lower in pregnant women whose total number of pregnancies, births and number of living children was one, women who wanted pregnancy, who received infertility treatment in the past, women with genetic abnormalities as the reason for termination of their pregnancy, and women whose pregnancy was not terminated before, however, the difference between the groups was not statistically significant ( $p>0.05$ ).

Table 3 presents the comparison of the scores obtained
Table 1. State-Trait Anxiety Inventory before termination of pregnancy according to the descriptive characteristics

$\begin{array}{lcc}\begin{array}{l}\text { Descriptive } \\ \text { Characteristics }\end{array} & \mathbf{n}(\%) & \begin{array}{c}\text { State-Trait Anxiety } \\ \text { Inventory }\end{array} \\ & & \text { Median (Min-Max) }\end{array}$

Age

$\begin{array}{llll}17-25 & 14(16.9) & 62.0(26.0-76.0) & \mathrm{KW}=1.308 \\ 26-34 & 44(53.0) & 65.0(27.0-80.0) & \mathrm{p}^{*}=0.520 \\ 35-43 & 25(30.1) & 62.0(37.0-72.0) & \end{array}$

Education

Primary school $\quad 25(30.1) \quad 59.0(27.0-76.0) \quad K W=2.009$

High school $\quad 22(26.5) \quad 62.0(48.0-80.0) \quad p^{*}=0.571$

Graduate $\quad 13(15.7) \quad 63.0(37.0-76.0)$

Postgraduate $\quad 23(27.7) \quad 65.0(26.0-80.0)$

Education of Spouse

$\begin{array}{llll}\text { Primary school } & 19(22.9) & 59.0(27.0-76.0) & \mathrm{KW}=2.682 \\ \text { High school } & 27(32.5) & 64.0(44.0-74.0) & \mathrm{p}^{*}=0.443 \\ \text { Graduate } & 23(27.7) & 63.0(26.0-80.0) & \\ \text { Postgraduate } & 14(16.9) & 66.5(37.0-80.0) & \\ \text { ork } & & & \end{array}$

$\begin{array}{llll}\text { Employed } & 28(33.7) & 62.5(26.0-80.0) & \mathrm{U}=720.000 \\ \text { Unemployed } & 55(66.3) & 62.0(27.0-76.0) & \mathrm{p}^{* *}=0.630\end{array}$

Economic status

Bad $\quad 7(8.4) \quad 55.0(49.0-70.0) \quad \mathrm{KW}=3.463$

Moderate $\quad 43(51.8) \quad 64.0(27.0-80.0) \quad \mathrm{p}^{*}=0.326$

Good $\quad 22(26.5) \quad 61.0(26.0-80.0)$

Very good $\quad 11(13.3) \quad 64.0(46.0-76.0)$

Consanguineous

marriages

$\begin{array}{lccc}\text { Yes } & 6(7.2) & 49.0(27.0-67.0) & \mathrm{U}=102.000 \\ \text { No } & 77(92.8) & 64.0(26.0-80.0) & \mathrm{p}^{* *}=0.021\end{array}$

${ }^{*}$ Kruskal Wallis test; ${ }^{* *}$ Mann-Whitney $\mathrm{U}$ test.

from the State-Trait Anxiety Inventory according to the feelings of pregnant women before termination and the need for psychological support. The mean State-Trait Anxiety Inventory scores of the pregnant women who felt fear before termination and in need of psychological support were higher, and the difference between groups was found to be statistically significant $(p=0.008, p=0.001$, respectively).

\section{DISCUSSION}

In this study, it was found that the mean State-Trait Anxiety Inventory scores of the pregnant women before termination were $60.7 \pm 11.6$ and that they experienced high levels of anxiety. In Ulufer's study, the mean pre-abortion anxiety score of women applied for abortion was 58.55. ${ }^{[18]}$ Ekşi's 
Table 2. State-Trait Anxiety Inventory before termination of pregnancy according to obstetric characteristics

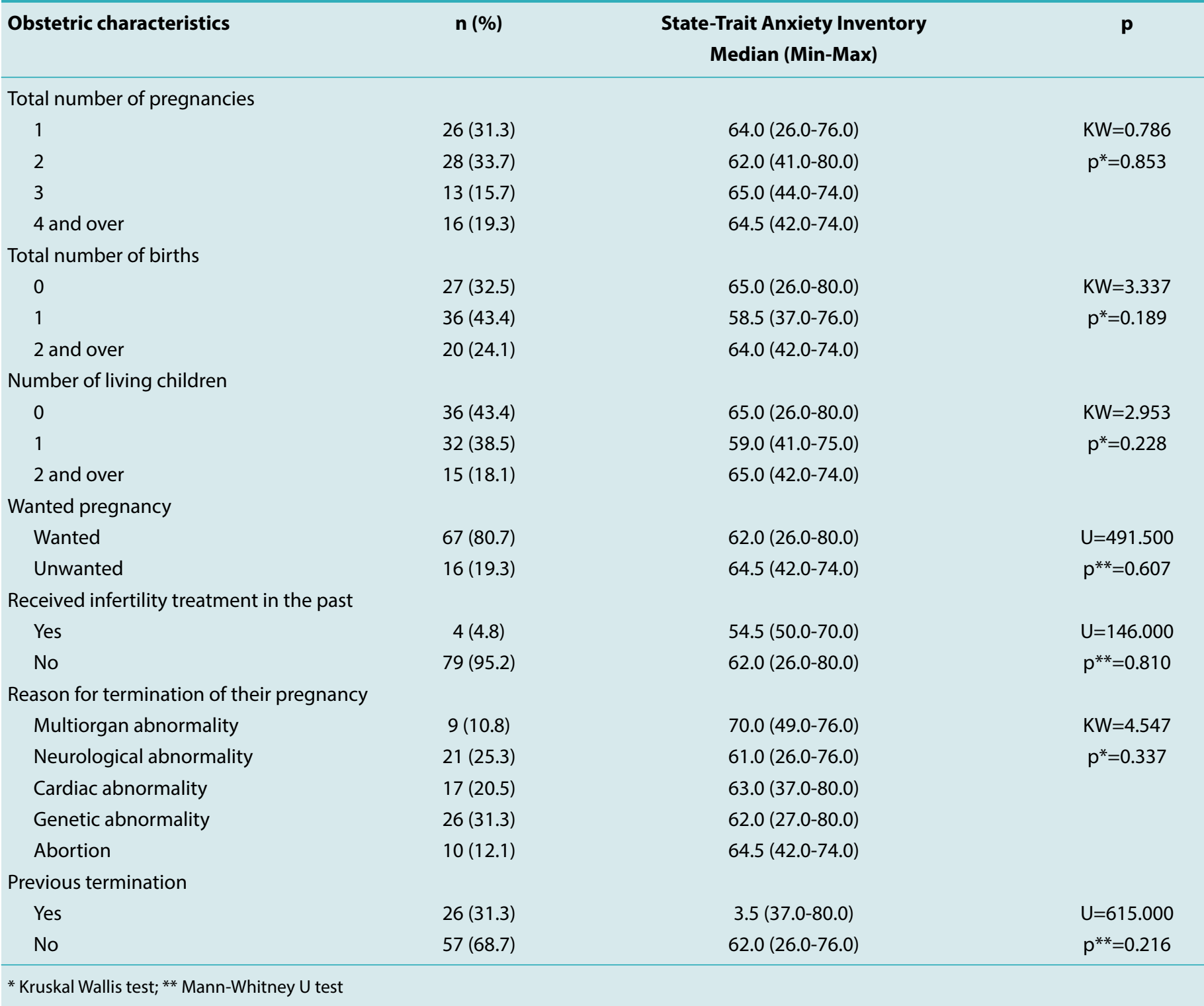

study found that the mean anxiety score of the pregnant women who lost their babies was 47.97, and the mean anxiety score of those who had the risk of losing their babies was 50.48. ${ }^{[19]}$

When the mean State-Trait Anxiety Inventory scores of pregnant women before termination of pregnancy were compared according to the descriptive characteristics of the pregnant women, the mean scores before termination of pregnancy were found to be higher in the pregnant women between 26-34 years of age, who and her husband had postgraduate degree, whose husband worked and had moderate/very good economic status, and who did not have consanguineous marriages. However, the difference between the groups was not statistically sig- nificant. When the State-Trait Anxiety Inventory scores of pregnant women who lost their babies were compared with women who had risk of losing their babies, in Ekşi's study, it was found that the mean score of the pregnant women between 16-25 years of age, who were illiterate/ literate and not working, were higher. However, the difference between the groups was not statistically significant. [19] When the mean State-Trait Anxiety Inventory scores were examined according to the descriptive characteristics of pregnant women in Güneştaş's study, there was no statistically significant difference between the age of the pregnant women, the education status of the women and her husband, the income status and the State-Trait Anxiety Inventory scores. When the working status of the pregnant women was examined, the findings showed that the mean 


\begin{tabular}{|c|c|c|c|}
\hline Patient's experience & n (\%) & $\begin{array}{c}\text { State-Trait Anxiety Inventory } \\
\text { Median (Min-Max) }\end{array}$ & $\mathbf{p}$ \\
\hline \multicolumn{4}{|c|}{ Feeling prior to pregnancy termination } \\
\hline Confusion & $6(7.2)$ & $61.0(49.0-75.0)$ & $K W=13.760$ \\
\hline Fear & $7(8.4)$ & $67.0(62.0-70.0)$ & \\
\hline Disappointment & $10(12.1)$ & $52.0(26.0-74.0)$ & \\
\hline Peace & $11(13.3)$ & $53.0(42.0-64.0)$ & \\
\hline \multicolumn{4}{|l|}{ Psychological support } \\
\hline Needed & $41(49.4)$ & $68.0(37.0-80.0)$ & $U=495.000$ \\
\hline
\end{tabular}

State-Trait Anxiety Inventory scores of the non-working pregnant women were significantly higher than the scores of the working pregnant women. ${ }^{[2]}$ When the mean StateTrait Anxiety Inventory scores were examined according to socio-demographic characteristics of pregnant women who applied for prenatal screening test in Cakır Kocak's study, the findings showed that the mean scores of the pregnant women who were literate-primary school graduates, who did not work, who perceived income status as moderate-bad and who had consanguineous marriages were higher, however, the difference between the groups was not statistically significant. ${ }^{[21]}$

When the scores obtained from the State-Trait Anxiety Inventory before termination were examined according to obstetric characteristics of pregnant women, the findings showed that the mean score received from the State-Trait Anxiety Inventory before termination was higher in pregnant women whose total number of pregnancies was four and more, who never gave birth before and who had two or more living children, women who did not want pregnancy, those who were not treated for infertility in the past, women with multiple organ failure as the reason for termination and women whose pregnancy was terminated previously. However, the difference between the groups was not statistically significant. In one study, that the findings showed that women who had four pregnancies, who had one miscarriage and one curettage, who had two children, who became pregnant voluntarily and who had health problems due to termination of pregnancy had a higher level of anxiety. ${ }^{[2]}$

When the scores obtained from the State-Trait Anxiety Inventory were compared according to the feelings of the pregnant women before the termination of pregnancy and the need for psychological support, the mean StateTrait Anxiety Inventory scores of pregnant women who felt fear before termination and in need of psychological support were higher, and the difference between the groups was statistically significant. Terzioğlu et al. found that pre-abortion anxiety scores of women were higher than post-abortion scores. ${ }^{[23]}$ Şahin et al. reported that $77.8 \%$ of women felt fear before abortion in their study, which examined pre-abortion emotions. ${ }^{[24]}$ In the study conducted by Oltuluoğlu et al., when the anxiety status of the women who applied for the abortion was examined, the findings showed that $61.4 \%$ experienced fear before the abortion. ${ }^{[25]}$

The hospital in which this study has been conducted was a university hospital, and the women applying for the detailed screening diagnoses have both reached the hospital through a referral from another hospital and by applying individually due to the advantages they have in education and socio-economic terms. The pregnant women in this study have had without a past medical history of anxiety disorders or any mental problems according to their own declaration. The study group is insufficient to reflect society. Further studies can be conducted with a wider and heterogenic population considering the limitations reported above.

\section{CONCLUSION}

Pregnancy termination is an important event in the life of the pregnant woman. Given that pregnancy will be terminated for a variety of reasons, albeit voluntarily, may lead to intense emotions, such as guilt, loss, regret and increased anxiety. For a mother, losing her baby may also mean los- 
ing a part of the body and the role of motherhood. Being unable to feel something living anymore can be very traumatic from a mental point of view.

By meeting a patient's needs with a holistic approach, we can significantly contribute to better rehabilitation. It is suggested that every pregnant woman who has been diagnosed with termination and her relatives should be informed in detail before and after termination. Psychosocial evaluation of pregnant women and their relatives in the terminating process, and determination of their needs, and the provision of psychosocial support and assistance according to the requirements identified are important. Training programs should be implemented for consultation-liaison psychiatry nurses, who have a special role in the termination process, to provide the patients and their relatives with effective psychosocial assistance. Termination of pregnancy for a fetal abnormality is ethically and morally challenging, which is beyond the scope of this paper.

\section{Disclosures}

Peer-review: Externally peer-reviewed.

Conflict of Interest: None declared.

Ethics Committee Approval: This study was approved by the Ethics Committee of Medipol University. (21/07/2016 No: 385).

Authorship Contributions: Concept -M.G.; Design - M.G., S.D.; Supervision - S.D.; Materials - M.G., S.D.; Data collection \&/or processing - M.G., S.D.; Analysis and/or interpretation - M.G., S.D., A.T.A; Literature search - M.G., S.D., A.T.A.; Writing - M.G., S.D., A.T.A.; Critical review - S.D., A.T.A.

\section{REFERENCES}

1. Bjelica A, Cetkovic N, Trninic-Pjevic A, Mladenovic-Segedi $\mathrm{L}$. The phenomenon of pregnancy - a psychological view. Ginekol Pol 2018;89(2):102-6. [CrossRef]

2. Ibrahim SM, Lobel M. Conceptualization, measurement, and effects of pregnancy-specific stress: review of research using the original and revised Prenatal Distress Questionnaire. J Behav Med 2019;1-18. [CrossRef]

3. Accortt EE, Wong MS. It is time for routine screening for perinatal mood and anxiety disorders in obstetrics and gynecology settings. Obstet Gynecol Surv 2017;72(9):553-68. [CrossRef]

4. Stevenson RE, Hall JG. Human Malformations and Related Anomalies. Oxford Universiy Press 2006. p. 58-71.

5. Feldman N, Melcer Y, Hod E, Levinsohn-Tavor O, Svirsky R, Maymon R. Termination of pregnancy due to fetal abnormalities performed after 32 weeks' gestation: survey of 57 fetuses from a single medical center. J Matern Fetal Neonatal Med 2018;31(6):740-6. [CrossRef]
6. Zirn B., Mehnert K. C Prenatal diagnostics. In: Guide for Genetic Consultation. Cham: Springer; 2019. p. 65-79.

7. Melcer Y, Svirsky R, Vaknin Z, Levinsohn-Tavor O, Feldman $\mathrm{N}$, Maymon R. Fetal abnormalities leading to termination of twin pregnancies: the 17-year experience of a single medical center. J Matern Fetal Neonatal Med 2017;30:347-51.

8. Lafarge C, Mitchell K, Breeze AC, Fox P. Pregnancy termination for fetal abnormality: are health professionals' perceptions of women's coping congruent with women's accounts?. BMC Pregnancy Childbirth 2017;17(1):60. [CrossRef]

9. Lipp A. Termination of Pregnancy: a Reviev of Psychological Effects on Women. Nurs Times 2009;105(1):26-9.

10. Broen AN, Moum T, Bödtker AS, Ekeberg O. Reasons For Induced Abortion And Their Relation To Women's Emotional Distress: A Porspective, Two-Yar Follow-Up Study. Gen Hosp Psychiatry 2005;27(1):36-43. [CrossRef]

11. Lafarge $C$, Mitchell $K$, Fox P. Perinatal grief following a termination of pregnancy for fetal abnormality: the impact of coping strategies. Prenat Diagn 2013;33(12):1173-82. [CrossRef]

12. Lafarge $C$, Mitchell K, Fox P. Women's experiences of coping with pregnancy termination for fetal abnormality. Qual Health Res 2013;23(7):924-36. [CrossRef]

13. Lafarge C, Mitchell K, Fox P. Posttraumatic growth following pregnancy termination for fetal abnormality: the predictive role of coping strategies and perinatal grief. Anxiety Stress Coping 2017;30(5):536-50. [CrossRef]

14. Carlsson T, Bergman G, Karlsson AM, Wadensten B, Mattsson E. Experiences of termination of pregnancy for a fetal anomaly: A qualitative study of virtual community messages. Midwifery 2016;41:54-60. [CrossRef]

15. McEvoy L, Duffy A. Holistic practice--a concept analysis. Nurse Educ Pract 2008;8(6):412-9. [CrossRef]

16. Spielberger CD, Gorsuch RL, Lushene RE. Manual for the State-Trait Anxiety Inventory. Palo Alto, CA: Consulting Psychologists Press; 1970.

17. Öner N, Compte A Le. Süreksiz durumluk/sürekli kaygı envanteri el kitabı. 2nd ed. İstanbul: Boğaziçi Üniversitesi; 1998.

18. Ulufer F. Kürtaja Başvuran Kadınların Kaygı Durumlarının İncelenmesi (tez). İzmir: Ege Üniversitesi Sağlık Bilimleri Enstitüsü. 1992.

19. Ekşi Z. 1. Trimesterda Bebeğini Kaybeden Ve Kaybetme Riski Olan Kadınların Kaygı Düzeyleri (tez). İstanbul: Marmara Üniversitesi Sağlık Bilimleri Enstitüsü. 1999.

20. Güneştaş İ. Gebelik Yaşının Kadınların Kaygı Düzeylerine Etkisinin İncelenmesi (tez). Samsun: Ondokuz Mayıs Üniversitesi Sağlık Bilimleri Enstitüsü. 2011.

21. Çakır Koçak Y. İlk Kez Anne-Baba Olacaklara Antenatel Dönemde Verilen Eğitimin Kaygı Düzeylerine Etkisi (tez). İzmir: Ege Üniversitesi Sağlık Bilimleri Enstitüsü. 2007.

22. Gül Ö. Gebeliklerini İsteğe Bağlı Sonlandıran Kadınların Yaşadıkları Anksiyetenin Psikososyal Durumlarına Etkisinin 
Incelenmesi (tez). İstanbul: İstanbul Bilim Üniversitesi Sağlık Bilimleri Enstitüsü. 2014.

23. Terzioğlu F, Zeyneloğlu S, Vefikuluçay Yılmaz D, Türk R, Gözükara F, Taşkın L. The Problems and Anxiety Levels of Women Who Had Elective or Therapeutic Abortion. Hacettepe University Faculty of Health Sciences Nursing Journal 2010; 3(4):18-29.
24. Şahin S, Cevahir R, Sözeri C. Sakarya Doğum ve Çocuk Bakımevi Hastanesi'ne İsteğe Bağlı Kürtaj İçin Başvuran Kadınların Değerlendirilmesi. Fırat Sağlık Hizmetleri Dergisi 2006;1(1):17-32.

25. Oltuluoğlu H, Budak F, Küçükkelepçe D, Günay U. Abortusa Başvuran Kadınların Kaygı Durumlarının İncelenmesi. İnönü Üniversitesi Sağlık Bilimleri Dergisi 2017;6(2):30-7. 